\title{
PENGARUH RETURN ON ASSET (ROA), NET PROFIT MARGIN (NPM), DEBT TO EQIUTY RATIO (DER), LEVERAGE OPERASI, DAN UKURAN PERUSAHAAN TERHADAP PRAKTIK PERATAAN LABA PADA PERUSAHAAN MANUFAKTUR SEKTOR INDUSTRI DASAR DAN KIMIA YANG TERDAFTAR DI BEI
}

\author{
Dien Sefty Framita \\ diensefty84@gmail.com \\ Universitas Serang Raya
}

\begin{abstract}
Abstrak
Penelitian ini bertujuan pengujian secara empirik tentang pengaruh return on asset (ROA), net profit margin (NPM), debt to eqiuty ratio (DER), leverage operasi, dan ukuran perusahaan terhadap praktik perataan laba. Penelitian ini dilakukan pada perusahaan manufaktur sektor industri dasar dan kimia yang terdaftar di Bursa Efek Indonesia yang menerbitkan laporan keuangan selama periode 2009-2012. Dengan menggunakan teknik purposive sampling diperoleh 22 sampel perusahaan dan dianalisis dengan menggunakan regresi linear berganda.

Hasil penelitian ini menunjukkan bahwa (1) return on asset berpengaruh terhadap perataan laba, (2) net profit margin berpengaruh terhadap perataan laba, (3) debt to equity ratio tidak berpengaruh terhadap perataan laba, (4) ukuran perusahaan tidak berpengaruh terhadap perataan laba, (5) leverage operasi tidak berpengaruh terhadap perataan laba, (6) nilai $\mathrm{R}^{2}$ sebesar 0,122 menunjukkan bahwa $12,2 \%$ variasi perataan laba dapat dijelaskan oleh variabel return on asset, net profit margin, debt to equity ratio, ukuran perusahaan, dan leverage operasi, serta sisanya $87,8 \%$ dijelaskan oleh faktor-faktor lain diluar model.
\end{abstract}

Kata kunci : Return on Asset (ROA), Net Profit Margin (NPM), Debt to Eqiuty Ratio (DER), Leverage Operasi, Praktik Perataan Laba.

\section{Pendahuluan}

Laporan keuangan merupakan media komunikasi yang digunakan untuk menghubungkan pihak-pihak yang berkepentingan terhadap perusahaan dan merupakan salah satu bentuk dari pertanggungjawaban perusahaan terhadap seluruh stakeholder perusahaan, seperti: manajemen, investor, kreditur, dan pemerintah. Dari laporan keuangan tersebut baik pihak eksternal maupun pihak internal perusahaan dapat meramalkan, membandingkan, dan menilai dampak keuangan yang timbul dari keputusan ekonomis yang diambilnya dari perusahaan, karena dalam laporan keuangan tersebut terdapat banyak informasi yang dibutuhkan oleh pihak-pihak tersebut, terutama adalah informasi tentang laba. Kehadiran perusahaan lain dapat mengakibatkan persaingan menjadi ketat dan pada akhirnya akan berimbas kepada ketidakstabilan laba yang diperoleh perusahaan. Persaingan tersebut dapat menyebabkan perusahaan bisa mendapatkan laba yang sangat tinggi kemudian akan menurun dengan drastis pada periode berikutnya, dan hal ini dipandang oleh investor sebagai lahan yang tidak aman untuk berinvestasi. Pada akhirnya, manajer dapat mengambil kesimpulan bahwa ada kecenderungan bahwa laba adalah satu-satunya hal yang diperhatikan dari seluruh bagian dalam laporan keuangan yang dikeluarkan oleh perusahaan. Kecenderungan tersebut memancing manajer untuk melakukan disfunctional behavior (perilaku tidak semestinya) dalam laporan keuangannya (Prabayanti dan Yasa, 2010), yaitu dengan melakukan perekayasaan laba (earning management). 
Manajemen laba yang salah satu polanya adalah perataan laba merupakan salah satu faktor yang dapat mengurangi kredibilitas laporan keuangan. Fluktuasi laba yang terjadi akan mendorong manajemen untuk mengelola labanya. Hal ini dilakukan untuk memberikan rasa aman kepada para investor. Perusahaan manufaktur sebagai emiten terbesar mempunyai peluang yang besar dalam memberikan kesempatan bagi para pelaku pasar atau investor untuk berinvestasi. Hal ini menjadikan perusahaan manufaktur selalu mendapatkan perhatian dan sorotan para pelaku pasar. Dari deskriptif mengenai perusahaan manufaktur tersebut maka tidak menutup kemungkinan terdapat indikasi manajemen dari beberapa perusahaan manufaktur melakukan tindakan perataan laba. Hal tersebut dapat dilihat dari laporan labarugi dari beberapa perusahaan menunjukkan besarnya laba yang relatif stabil dari tahun ke tahun. Income smoothing hypotesis merupakan salah satu tindakan manajer yang dapat menjelaskan manajemen laba, yaitu tindakan menaksir bahwa laba dapat dimanipulasi untuk mengurangi fluktuasi sekitar tingkat yang dipertimbangkan normal bagi perusahaan (Bartov, 1993 dalam Nugroho 2008). Praktik perataan laba merupakan suatu fenomena umum dan banyak terjadi di beberapa negara (Dewi dan Carina, 2008). Tindakan earnings management telah memunculkan beberapa kasus skandal pelaporan akuntansi yang secara luas diketahui, antara lain Enron, Merck, WorldCom, dan mayoritas perusahaan lain di Amerika Serikat (Cornett et al.,2006). Yang ada di indonesia adalah seperti insider trading pada saham PT Bank Central Asia tahun 2001 maupun kasus laporan keuangan ganda PT Bank Lippo pada tahun 2002 yang diterbitkan oleh pihak manajemen perusahaan yang melibatkan pelaporan keuangan (financial reporting) yang berawal dari terdeteksi adanya manipulasi laba, Boediono (2005).

Terdapat bebeberapa faktor-faktor pendorong perataan laba tersebut pada umumnya dapat dibedakan atas faktor konsekuensi ekonomi dari pilihan akuntansi dan faktor-faktor laba (Moses, 1987 dalam Sitinjak, 2011). Faktor konsekuensi ekonomi lebih dipengaruhi oleh angka-angka akuntansi. Return on asset, net profit margin, debt to equity ratio, ukuran perusahaan dan operating leverage, merupakan contoh-contoh dari kondisi yang dipengaruhi oleh angka-angka akuntansi, sehingga setiap perubahan akuntansi yang dilakukan oleh perusahaan akan mempengaruhi setiap kondisi dimana saat perubahan tersebut dilakukan, sedangkan untuk faktor laba, yang mampu mempengaruhi adalah angka-angka laba itu sendiri yang akan mendorong perilaku perataan laba oleh manajer. Misalnya perbedaan yang terjadi pada laba yang diharapkan dengan laba aktual. Semakin besar perbedaan yang terjadi maka semakin besar motivasi manajer untuk meratakan laba sesuai dengan yang diharapkan.

Dalam hubungan keagenan, manajer memiliki asimetri informasi terhadap pihak eksternal perusahaan seperti kreditor dan investor yang terjadi ketika manajer memiliki informasi internal perusahaan lebih banyak dan cepat dibanding pihak eksternal. Dengan menggunakan asumsi risk averse (risiko menghindari atau menolak), maka investor dan kreditor enggan untuk menanamkan modalnya atau meminjamkan dananya bila perusahaan tersebut memiliki rasio leverage yang besar. Dalam kondisi demikian manajer dapat menggunakan informasi yang diketahuinya untuk memanipulasi laporan keuangan perusahaan dalam usaha memaksimalkan kemakmurannya dengan cara melakukan tindakan perataan laba. Dari uraian diatas diperoleh adanya perbedaan hasil penelitian (research gap) yang dilakukan oleh para peneliti serta perbedaan antara realita dan teori (research problem). Research gap dan research problem yang telah dipaparkan diatas dapat dijadikan permasalahan dalam penelitian ini. Pada penelitian ini menggunakan indeks eckel sebagai indikator terjadinya perataan laba. Berdasarkan fenomena tindakan nyata dan research gap yang ada, maka tujuan dari penelitian ini adalah untuk menganalisis pengaruh Return on Asset (ROA), Net Profit Margin (NPM), Debt to Eqiuty Ratio (DER), Ukuran Perusahaan, dan 
Leverage Operasi terhadap Praktik Perataan Laba pada perusahaan manufaktur sektor industri dasar dan kimia yang terdaftar di BEI.

\section{Tinjauan Teori dan Pengembangan Hipotesa Perataan Laba (Income Smoothing)}

Perataan laba merupakan tindakan yang dilakukan dengan sengaja untuk mengurangi variabilitas laba yang dilaporkan agar dapat mengurangi risiko pasar atas saham perusahaan, yang pada akhirnya dapat meningkatkan harga saham perusahaan (Assih dkk., 2000).

\section{Return on Asset (ROA)}

Return on Asset (ROA) digunakan untuk mengukur kemampuan manajemen dalam memperoleh keuntungan (laba) secara keseluruhan. ROA berfungsi untuk mengukur efektivitas perusahaan dalam menghasilkan laba melalui pengoperasian aktiva yang dimiliki. Semakin besar ROA yang dimiliki oleh sebuah perusahaan maka semakin efisien penggunaan aktiva sehingga akan memperbesar laba.

\section{Net Profit Margin (NPM)}

Net Profit Margin adalah perbandingan antara laba bersih dengan penjualan. Semakin besar NPM, maka kinerja perusahaan akan semakin produktif, sehingga akan meningkatkan kepercayaan investor untuk menanamkan modalnya pada perusahaan tersebut.

\section{Debt to Equity (DER)}

DER menggambarkan komposisi/struktur modal perusahaan yang digunakan sebagai sumber pendanaan usaha. Semakin tinggi DER menunjukkan semakin tinggi komposisi utang perusahaan dibandingkan dengan modal sendiri sehingga berdampak besar pada beban perusahaan terhadap pihak luar (Ang, 1997) karena akan menurunkan tingkat solvabilitas perusahaan. Penggunaan utang tersebut bagi perusahaan mengandung tiga dimensi yaitu: pemberi kredit akan menitik beratkan pada besarnya jaminan atas kredit yang diberikan, dengan menggunakan utang maka apabila perusahaan mendapatkan keuntungan yang lebih besar dari beban tetapnya maka pemilik perusahaan keuntungannya akan meningkat, dan dengan menggunakan utang maka pemilik memperoleh dana dan tidak kehilangan pengendalian perusahaan.

\section{Ukuran Perusahaan}

Menurut Juniarti dan Corolina (2005) menyebutkan perusahaan yang berukuran besar akan cenderung melakukan praktik perataan laba dibandingkan perusahaan yang berukuran kecil, karena perusahaan besar cenderung mendapatkan perhatian yang lebih besar dari analis dan investor dibandingkan perusahaan kecil. Oleh karena itu perusahaan besar akan menghindari fluktuasi laba yang terlalu drastis, sebab kenaikan laba akan menyebabkan bertambahnya pajak. Sebaliknya penurunan laba akan memberikan image perusahaan yang kurang baik. Oleh karena itu perusahaan besar akan cenderung melakukan praktik perataan laba (Budiasih, 2009).

\section{Leverage Operasi}

Dengan menggunakan asumsi risk averse (risiko menghindari atau menolak), maka investor dan kreditor enggan untuk menanamkan modalnya atau meminjamkan dananya bila perusahaan tersebut memiliki rasio leverage yang besar. Dalam kondisi demikian manajer dapat menggunakan informasi yang diketahuinya untuk memanipulasi laporan keuangan 
perusahaan dalam usaha memaksimalkan kemakmurannya dengan cara melakukan tindakan perataan laba.

\section{Pengembangan Hipotesis}

Adapun rumusan hipotesis yang dapat dibuat adalah sebagai berikut :

$\mathrm{H}_{1}$ : Return on asset berpengaruh terhadap praktik perataan laba.

$\mathrm{H}_{2}$ : Net profit margin operasi berpengaruh terhadap praktik perataan laba.

$\mathrm{H}_{3}$ : Debt to equity ratio operasi berpengaruh terhadap praktik perataan laba.

$\mathrm{H}_{4}$ : Ukuran perusahaan berpengaruh terhadap praktik perataan laba.

$\mathrm{H}_{5}$ : Leverage operasi berpengaruh terhadap praktik perataan laba.

\section{Metodologi Penelitian}

Penelitian ini penulis melakukan jenis penelitian pengembangan. Dalam penelitian ini peneliti menggunakan riset kuantitatif dengan melakukan pengujian terhadap hipotesis, dengan menggunakan sampel yang mencerminkan populasi dengan menggunakan data sekunder. Penelitian ini mendasarkan pada penelitian sebelumnya yang dilakukan oleh Igan Budiasih (2009), dengan menggunakan beberapa variabel independen yang berbeda dengan yang dilakukan oleh Igan Budiasih (2009), jadi penelitian ini bersifat modifikasi. Populasi yang digunakan dalam penelitian ini adalah semua perusahaan manufaktur sektor industri dasar dan kimia yang terdaftar di Bursa Efek Indonesia selama periode penelitian yaitu dari tahun 2009-2012 yang terdiri dari 58 perusahaan. Dengan menggunakan sampel porposive

\section{Definisi dan Operasional Variabel}

\section{Definisi dan Operasional Variabel}

\begin{tabular}{|c|c|c|c|c|}
\hline No. & $\begin{array}{c}\text { Nama } \\
\text { Variabel } \\
\end{array}$ & Definisi Operasional & Rumus & Skala \\
\hline 1 & $\begin{array}{l}\text { Return on } \\
\text { Asset (ROA) }\end{array}$ & $\begin{array}{l}\text { Return on Asset digunakan } \\
\text { untuk mengukur kemampuan } \\
\text { manajemen dalam memperoleh } \\
\text { keuntungan } \\
\text { (laba) secara keseluruhan }\end{array}$ & $\mathrm{ROA}=\frac{\mathrm{EAT}}{\text { Total Asset }} \times 100 \%$ & Rasio \\
\hline 2 & $\begin{array}{l}\text { Debt to } \\
\text { Equity Ratio } \\
(\text { DER })\end{array}$ & 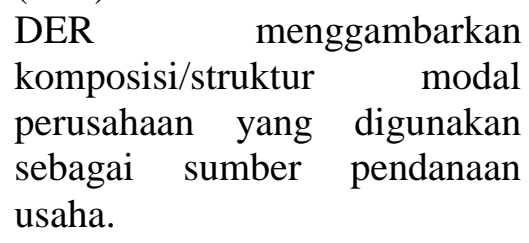 & DER $=\frac{\text { Total Hutang }}{\text { Ekuitas }} \times 100 \%$ & Rasio \\
\hline 3 & $\begin{array}{l}\text { Net Profit } \\
\text { Margin } \\
(N P M)\end{array}$ & $\begin{array}{lr}\text { Net Profit Margin } & \text { (NPM) } \\
\text { digunakan } & \text { untuk } \\
\text { menunjukkan } & \text { kemampuan } \\
\text { perusahaan } & \text { dalam } \\
\text { menghasilkan } & \text { keuntungan } \\
\text { bersih setelah dipotong pajak. } \\
\text { Rasio ini menunjukkan } \\
\text { berapa besar persentase laba } \\
\text { bersih yang diperoleh dari } \\
\text { setiap penjualan. }\end{array}$ & $\mathrm{NPM}=\frac{\mathrm{EAT}}{\text { Penjualan }} \times 100 \%$ & Rasio \\
\hline 4 & $\begin{array}{l}\text { Ukuran } \\
\text { Perusahaan }\end{array}$ & $\begin{array}{l}\text { Ukuran perusahaan adalah } \\
\text { sakala untuk menentukan besar } \\
\text { kecilnya perusahaan }\end{array}$ & $\begin{array}{l}\text { Ukuran perusahaan } \\
\text { Total Aktiva }\end{array}$ & Rasio \\
\hline
\end{tabular}




\section{$5 \quad$ Leverage Operasi}

\section{Leverage} memperlihatkan

operasi penjualan terhadap laba operasi atau laba sebelum bunga dan pajak (EBIT) yang diperoleh.
DOL $=\frac{\% \text { perubahan EBIT }}{\% \text { perubahan penjualan }} \times 100 \% \quad$ Rasio

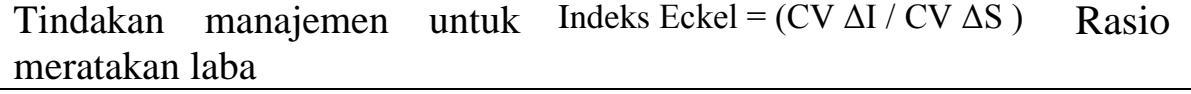

\section{Rancangan Analisis dan Uji Hipotesis}

Rancangan analisis dalam penelitian ini adalah kuantitatif menggunakan statistik yang terdiri dari statistik deskriptif dan statistik parametrik yang harus memenuhi asumsi yaitu uji asumsi klasik sebelum melakukan uji hipotesis. Uji asumsi klasik ini meliputi uji normalitas, uji multikoleniaritas, uji heteroskedastisitas dan uji autokorelasi. Setelah semua data lulus uji asumsi klasik yang selanjutnya membuat persamaan regresi liniear berganda dan terakhir uji hipotesis yang terdiri dari uji koefisien determinasi, uji statistik t dan uji statistik F.

Variabel dependen dalam penelitian ini adalah Perataan laba, Variabel independen dalam penelitian ini adalah return on asset, debt to equity ratio, net profit margin, ukuran perusahaan, dan leverage operasi.

Berdasarkan variabel-variabel diatas persamaan regresi berganda untuk menguji hipotesis pada penelitian ini adalah sebagai berikut:

$\mathrm{Y}=\alpha+\beta 1 \mathrm{X} 1+\beta 2 \mathrm{X} 2+\beta 3 \mathrm{X} 3+\beta 4 \mathrm{X} 4+\beta 5 \mathrm{X} 5+\mathrm{e}$

$\mathrm{Y}=$ Perataan Laba

$\alpha=$ Konstanta, $\beta 1-\beta 5=$ Koefisien regresi, $\mathrm{X} 1=$ Return on asset, $\mathrm{X} 2=\mathrm{Net}$ profit margin, $\mathrm{X} 3$

$=$ Debt to equity ratio, $\mathrm{X} 4=$ Ukuran perusahaan, $\mathrm{X} 5=$ Leverage operasi, $\mathrm{e}=$ error

\section{Hasil dan Pembahasan Regresi Linier Berganda}

\begin{tabular}{|c|c|c|c|c|c|c|c|c|}
\hline \multicolumn{9}{|c|}{$\begin{array}{c}\text { Hasil Regresi Berganda } \\
\text { Coefficients }^{\mathrm{a}}\end{array}$} \\
\hline & & \multicolumn{2}{|c|}{$\begin{array}{l}\text { Unstandardized } \\
\text { Coefficients }\end{array}$} & \multirow{2}{*}{$\begin{array}{c}\text { Standardized } \\
\text { Coefficients } \\
\text { Beta }\end{array}$} & \multirow[b]{2}{*}{$\mathrm{T}$} & \multirow[b]{2}{*}{ Sig. } & \multicolumn{2}{|c|}{ Collinearity Statistics } \\
\hline \multicolumn{2}{|c|}{ Model } & B & Std. Error & & & & Tolerance & VIF \\
\hline 1 & (Constant) & .761 & .726 & & 1.048 & .309 & & \\
\hline & ROA & .020 & .440 & .004 & 1.996 & .014 & .705 & 1.419 \\
\hline & NPM & .133 & .092 & .164 & 2.454 & .039 & .707 & 1.415 \\
\hline & DER & -.032 & .091 & -.086 & -.353 & .728 & .870 & 1.149 \\
\hline & SIZE & -.017 & .056 & -.075 & -1.298 & .769 & .816 & 1.226 \\
\hline & DOL & -.082 & .107 & -.216 & -.771 & .451 & .654 & 1.528 \\
\hline
\end{tabular}

a. Dependent Variable: IS

Berdasarkan hasil pengujian pada tabel diatas maka dapat dibuat bentuk persamaan sebagai berikut: $\mathrm{Y}=0,761+0,020 \mathrm{ROA}+$ 0,133 NPM - 0,032 DER - 0,017 SIZE - 0,082 DOL

\section{Hasil Uji Koefisien Determinasi $\left(\mathbf{R}^{2}\right)$}

Koefisien determinasi $\left(\mathrm{R}^{2}\right)$ digunakan untuk mengukur seberapa jauh kemampuan model dalam menerangkan variasi variabel independen terhadap variabel dependen. Hasil uji determinasi menghasilkan output sebagaimana dalam tabel 4.3. dibawah ini: 
Uji Koefisien Determinasi

\begin{tabular}{llrrr}
\hline Model & R & R Square & \multicolumn{1}{c}{$\begin{array}{c}\text { Adjusted R } \\
\text { Square }\end{array}$} & $\begin{array}{c}\text { Std. Error of the } \\
\text { Estimate }\end{array}$ \\
\hline 1 & 0,349 & 0,122 & 0,135 & 0,342 \\
\hline
\end{tabular}

Berdasarkan hasil uji determinasi diketahui bahwa nilai $\mathrm{R}$ square sebesar 0,122 , hal ini berarti bahwa $12,2 \%$ variasi perataan laba bisa dijelaskan oleh return on asset, net profit margin, debt to equity ratio, ukuran perusahaan dan leverage operasi, sedangkan sisanya 87,8 $\%$ dijelaskan oleh faktor-faktor lain diluar model, seperti dividend payout ratio, kepemilikan institusional, resiko dan kompensasi bonus.

\section{Hasil Uji Signifikansi Simultan (Uji Statistik F)}

Hasil uji statistik $\mathrm{F}$ digunakan untuk mengetahui apakah variabel independen yang terdapat dalam persamaan regresi secara bersama-sama berpengaruh terhadap nilai variabel dependen. Kesimpulan yang diambil dalam uji $\mathrm{F}$ ini adalah dengan melihat signifikansi $(\alpha)$. Derajat signifikansi yang digunakan adalah 0,05. Dan dengan membandingkan antara F tabel dengan $\mathrm{F}$ hitung. Hasil uji statistik $\mathrm{F}$ menghasilkan output sebagaimana dalam tabel 4.4 berikut ini:

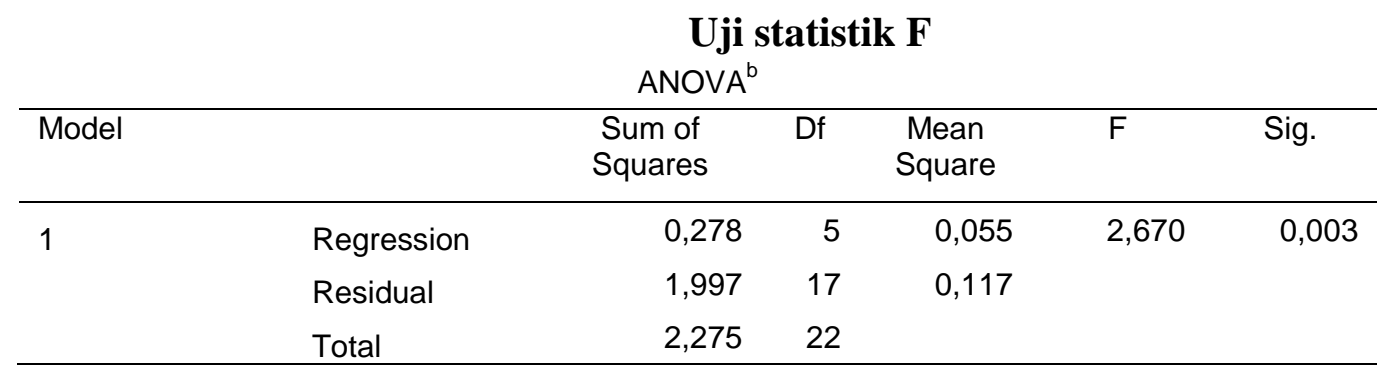

Berdasarkan tabel uji $\mathrm{F}$ diatas menunjukkan nilai sig-nya sebesar 0,003 $<0,05$ dan nilai $\mathrm{F}$ hitung 2,670 > F tabel 2,33 dapat disimpulkan bahwa semua variabel secara bersamasama berpengaruh signifikan terhadap perataan laba.

\section{Hasil Uji Signifikansi Parameter Individual (Uji Statistik t)} Coefficients $^{\mathrm{a}}$

\begin{tabular}{llccccccc}
\hline & \multicolumn{2}{c}{$\begin{array}{c}\text { Unstandardized } \\
\text { Coefficients }\end{array}$} & \multicolumn{2}{c}{$\begin{array}{c}\text { Standardized } \\
\text { Coefficients }\end{array}$} & \multicolumn{3}{c}{ Collinearity Statistics } \\
Model & B & Std. Error & Beta & T & Sig. & Tolerance & VIF \\
\hline $1 \quad$ (Constant) & .761 & .726 & & 1.048 & .309 & & \\
ROA & .020 & .440 & .004 & 1.996 & .014 & .705 & 1.419 \\
NPM & .133 & .092 & .164 & 2.454 & .039 & .707 & 1.415 \\
DER & -.032 & .091 & -.086 & -.353 & .728 & .870 & 1.149 \\
SIZE & -.017 & .056 & -.075 & -1.298 & .769 & .816 & 1.226 \\
DOL & -.082 & .107 & -.216 & -.771 & .451 & .654 & 1.528 \\
\hline
\end{tabular}

a. Dependent Variable: IS

\section{Pengujian Hipotesis Pertama}

Berdasarkan tabel 4.6, nilai $\mathrm{t}$ hitung sebesar 1,996 > t tabel 1,989 dengan tingkat signifikansi menunjukkan $0,014<0,05$ hal ini berarti $\mathrm{H}_{\mathrm{a}} 1$ diterima dan $\mathrm{H}_{0} 1$ di tolak yang berarti bahwa return on asset berpengaruh terhadap perataan laba. Jika perusahaan memiliki ROA yang tinggi, menandakan bahwa laba yang diperoleh perusahaan tinggi. Dengan laba 
yang tinggi maka manajemen dengan mudah dapat mengatur labanya (Assih dkk, 2007 dalam Prabayanti dan Yasa, 2010). Perusahaan yang mempunyai laba yang tinggi akan cenderung melakukan praktik perataan laba karena perusahaan akan menurunkan laba saat memperoleh laba yang tinggi (Prabayanti dan Yasa, 2010). Tingkat laba yang stabil memiliki keuntungan bagi manajemen, yaitu mengamankan posisi jabatan dalam perusahaan karena manajemen terlihat memiliki kinerja yang baik jika dinilai dari kemampuan laba yang dihasilkan. Tingkat laba yang stabil juga memberikan kayakinan kepada investor atas investasi yang dilakukan karena perusahaan dinilai baik dalam menghasilkan laba.

Hasil penelitian ini sejalan dengan hasil penelitian yang dilakukan oleh empat peneliti sebelumnya, yaitu Juniarti dan Carolina (2005), Budhijono (2006), Igan Budiasih (2009), Ni Luh Putu Arik Prabayanti dan Geriawan Wirawan Yasa (2010) yang menemukan bahwa return on asset berpengaruh terhadap perataan laba. Hasil penelitian ini berbeda dengan Muhammad Yusuf dan Soraya (2004), Edy Suwito dan Arleen Herawaty (2005), dan Dhamar Yudho Aji dan Aria Farah Mita (2010) yang menemukan bahwa return on asset tidak berpengaruh terhadap perataan laba, dengan alasan karena semakin tinggi tingkat ROA maka perusahaan tersebut akan menjadi sorotan publik, sehingga perusahaan kemungkinan berusaha untuk tidak melakukan perataan laba karena akan membahayakan kredibilitas perusahaan.

\subsubsection{Pengujian Hipotesis Kedua}

Berdasarkan uji hoptesis pada tabel 4.6 diatas nilai t hitung menunjukkan 2,454 > t tabel 1,989 dengan tingkat signifikansi $0,039<0,05$. Hal ini berarti bahwa $\mathrm{H}_{\mathrm{a}} 2$ diterima dan $\mathrm{H}_{0} 2$ di tolak yang berarti bahwa net profit margin berpengaruh terhadap perataan laba. Semakin besar net profit margin, maka kinerja perusahaan akan semakin produktif, sehingga akan meningkatkan kepercayaan investor untuk menanamkan modalnya pada perusahaan tersebut. Rasio ini menunjukkan berapa besar persentase laba bersih yang diperoleh dari setiap penjualan. Semakin besar rasio ini, maka dianggap semakin baik kemampuan perusahaan untuk mendapatkan laba yang tinggi. Hubungan antara laba bersih sesudah pajak dan penjualan bersih menunjukkan kemampuan manajemen dalam mengemudikan perusahaan secara cukup berhasil untuk menyisakan margin tertentu sebagai kompensasi yang wajar bagi pemilik yang telah menyediakan modalnya untuk suatu risiko. Dengan mengetahui hal tersebut investor dapat menilai apakah perusahaan itu profitable atau tidak.

Menurut penelitian yang dilakukan oleh Septoaji (2002), net profit margin mempunyai pengaruh terhadap perataan laba karena jika net profit margin tinggi maka perusahaan akan mempunyai nilai tambah bagi para investor. Hal yang sama juga ditunjukkan terhadap para calon investor potensial, dimana diharapkan mereka akan tertarik membeli saham perusahaan. Dengan demikian, perusahaan akan cenderung melakukan perataan laba agar net profit margin-nya selalu baik. Hasil penelitian ini tidak sejalan dengan hasil penelitian sebelumnya yang dilakukan oleh Edy Suwito dan Arleen Herawaty (2005) yang menemukan bahwa net profit margin tidak berpengaruh terhadap perataan laba, karena kemungkinan perusahaan menggunakan pendanaan hutang yang cukup besar, sehingga struktur modalnya optimal dan menghasilkan laba yang relatif rendah. Margin laba yang rendah menunjukkan tidak ada masalah dalam operasi perusahaan sehingga perusahaan memiliki tingkat pengembalian yang tinggi bagi para pemegang saham.

\section{Pengujian Hipotesis Ketiga}

Berdasarkan uji hipotesis pada tabel 4.6 untuk variabel debt to equity ratio ini menghasilkan nilai $\mathrm{t}$ hitung $0,353<\mathrm{t}$ tabel 1,989 dan tingkat signifikansi sebesar $0,728>$ 0,05 . Hal ini menunjukkan bahwa $\mathrm{H}_{\mathrm{a}} 3$ ditolak dan $\mathrm{H}_{0} 3$ di terima yang berarti bahwa variabel 
debt to equity ratio tidak berpengaruh terhadap perataan laba. Ini berarti bahwa tinggi atau rendahnya debt to equity ratio tidak berpengaruh terhadap perataan laba, karena perusahaan yang dijadikan sampel dalam penelitian memiliki tingkat hutang yang rendah, sehingga dalam membiayai aktivanya perusahaan tidak bergantung pada hutang.

Namun demikian secara hubungan, menurut Weston et al dalam Marlina (2001) yang menyatakan bahwa seorang kreditur akan memberikan kredit pada perusahaan yang mempunyai rasio hutang lebih kecil daripada modalnya sendiri, dan seorang kreditur akan memberikan kredit pada perusahaan yang mempunyai laba yang stabil karena laba yang stabil memberikan keyakinan pada kreditur bahwa perusahaan akan mampu membayar hutangnya. Hasil penelitian ini sejalan dengan hasil penelitian sebelumnya yang dilakukan oleh Yurianto dan Gudono (2002) yang menemukan bahwa debt to equity ratio tidak berpengaruh terhadap perataan laba.

\section{Pengujian Hipotesis Keempat}

Berdasarkan tabel 4.6 diatas nilai t hitung 1,298< $\mathrm{t}$ tabel 1,989 dengan tingkat signifikasi sebesar 0,769>0,05. Hal ini menunjukkan bahwa $\mathrm{H}_{\mathrm{a}} 4$ ditolak dan $\mathrm{H}_{0} 4$ di terima yang berarti bahwa variabel ukuran perusahaan tidak berpengaruh terhadap perataan laba. Ini berarti besar atau kecilnya ukuran perusahaan tidak berpengaruh terhadap perataan laba. Bisa jadi karena perusahaan yang besar tidak tidak selamanya diidentikkan dengan padat modal tetapi bisa jadi padat karya, sehingga total aktiva kurang tepat dalam untuk menjadi tolok ukur size perusahaan.

Namun demikian secara hubungan, pada saat nilai ukuran perusahaan meningkat kecenderungan perusahaan untuk melakukan perataan laba menurun. Dengan demikian dapat disimpulkan bahwa semakin besar ukuran perusahaan maka semakin banyak pula informasi yang tersedia bagi pengguna laporan keuangan dalam pengambilan keputusan. Perusahaan yang berukuran besar memiliki kecenderungan melakukan tindakan perataan laba lebih kecil dibanding perusahaan yang ukurannya lebih kecil. Hal ini dikarenakan perusahaan besar dipandang lebih kritis oleh pemegang saham dan pihak luar. Sehingga perusahaan besar mendapatkan tekanan yang lebih kuat untuk menyajikan pelaporan keuangan yang credible. Hasil penelitian ini sejalan dengan hasil penelitian yang dilakukan oleh Edy Suwito dan Arleen Herawaty (2005), Juniarti dan Carolina (2005), Ni Luh Putu Arik Prabayanti dan Geriawan Wirawan Yasa Dhamar Yudho Aji dan Aria Farah Mita (2010) yang menemukan bahwa ukuran perusahaan tidak berpengaruh terhadap perataan laba. Hasil penelitian ini tidak sejalan dengan hasil penelitian sebelumnya yang dilakukan oleh Budhijono (2006), Igan Budiasih (2009), Muhammad Yusuf dan Soraya (2004) yang menemukan bahwa ukuran perusahaan berpengaruh terhadap perataan laba.

\section{Pengujian Hipotesis Kelima}

Berdasarkan uji hipotesis pada tabel 4.6 diatas nilai t hitung menunjukkan $0,771<\mathrm{t}$ tabel 1,989 dengan tingkat signifikansi 0,451>0,05. Hal ini menunjukkan bahwa $\mathrm{H}_{\mathrm{a}} 5$ ditolak dan $\mathrm{H}_{0} 5$ di terima yang berarti bahwa variabel leverage operasi tidak berpengaruh terhadap perataan laba. Hal ini berarti tinggi atau rendahnya leverage operasi tidak berpengaruh terhadap perataan laba. Hal ini dikarenakan perusahaan selalu diawasi oleh pihak eksternal khususnya kreditor dan investor sehingga dalam memberikan informasi laporan keuangan sehingga perusahaan akan lebih berhati-hati untuk tidak melakukan manipulasi. Dengan adanya keterikatan perusahaan dengan persyaratan-persyaratan dalam perjanjian yang diajukan oleh kreditor atau investor serta aturan main dalam Standar Akuntansi yang harus dipenuhi akan sulit sekali bagi perusahaan untuk melakukan manipulasi laporan keuangan, 
misalnya merubah informasi mengenai besarnya laba, penjualan bahkan biaya baik variabel maupun tetap.

Namun demikian dalam hubungan keagenan, manajer memiliki asimetri informasi terhadap pihak eksternal perusahaan seperti kreditor dan investor yang terjadi ketika manajer memiliki informasi internal perusahaan lebih banyak dan cepat dibanding pihak eksternal. Dengan menggunakan asumsi risk averse (risiko menghindari atau menolak), maka investor dan kreditor enggan untuk menanamkan modalnya atau meminjamkan dananya bila perusahaan tersebut memiliki rasio leverage yang besar. Dalam kondisi demikian manajer dapat menggunakan informasi yang diketahuinya untuk memanipulasi laporan keuangan perusahaan dalam usaha memaksimalkan kemakmurannya dengan cara melakukan tindakan perataan laba. Hasil penelitian ini sejalan dengan hasil penelitian sebelumnya yang dilakukan oleh Budhijono (2006) yang menemukan bahwa leverage operasi tidak berpengaruh terhadap perataan laba. Hasil penelitian ini tidak sejalan dengan hasil penelitian sebelumnya yang dilakukan oleh Muhammad Yusuf dan Soraya (2004) yang menemukan bahwa leverage operasi berpengaruh terhadap perataan laba.

\section{Kesimpulan dan Saran}

Penelitian ini berupaya untuk membuktikan adanya pengaruh return on asset, net profit margin, debt to equity ratio, ukuran perusahaan, dan leverage operasi terhadap perataan laba pada perusahaan manufaktur sektor industri dasar dan kimia yang terdaftar di Bursa Efek Indonesia (BEI) selama periode 2009-2012. Dari hasil pengujian regresi linear berganda ditemukan hasil sebagai berikut: Return on asset berpengaruh terhadap perataan laba. Hal ini berarti bahwa jika nilai return on asset meningkat kecenderungan perusahaan untuk melakukan perataan laba meningkat. Net profit margin berpengaruh terhadap perataan laba. Hal ini berarti bahwa apabila nilai net profit margin meningkat kecenderungan perusahaan untuk melakukan perataan laba meningkat. Debt to equity ratio tidak berpengaruh terhadap perataan laba. Hal ini berati tinggi atau rendahnya debt to equity ratio tidak berpengaruh terhadap perusahaan melakukan perataan laba atau tidak. Ukuran perusahaan tidak berpengaruh terhadap perataan laba. Hal ini berati besar atau kecilnya perusahaan tidak berpengaruh terhadap perusahaan melakukan perataan laba atau tidak. Leverage operasi tidak berpengaruh terhadap perataan laba. Hal ini berarti tinggi atau rendahnya leverage operasi tidak berpengaruh terhadap perataan laba. Berdasarkan nilai $\mathrm{R}^{2}$ sebesar 0,122 menunjukkan bahwa $12,2 \%$ variasi perataan laba dapat dijelaskan oleh variabel return on asset, net profit margin, debt to equity ratio, ukuran perusahaan, dan leverage operasi, serta sisanya $87,8 \%$ dijelaskan oleh faktor-faktor lain diluar model.

Berdasarkan kesimpulan di atas, maka saran-saran yang dapat diberikan melalui hasil penelitian ini baik kepada investor, perusahaan maupun untuk pengembangan penelitian yang lebih lanjut adalah sebagai berikut: Saran untuk investor, Mengingat hasil penelitian ini menyatakan bahwa return on asset dan net profit margin berpengaruh terhadap praktik perataan laba dalam perusahaan, maka dalam mengambil keputusan hendaknya investor tidak hanya memperhatikan informasi mengenai laba perusahaan tetapi akan lebih baik memperhatikan banyak aspek selain laba, misalnya memperhatikan cashflow perusahaan dan kondisi ekonomi pada saat ini. Laba yang terlihat stabil dari tahun ke tahun belum tentu mencerminkan tingkat profitabilitas yang sesungguhnya. Oleh karena itu, disarankan untuk para investor agar mencermati perubahan dalam pos-pos Laporan Keuangan yang dapat mempengaruhi angka laba, misalnya dengan cara menilai kecukupan pengungkapan yang mendukung kewajaran atas perubahan tersebut. Saran untuk peneliti selanjutnya, Pertimbangkan penggunaan variabel-variabel independen lain diluar model penelitian ini agar dapat diketahui faktor-faktor lain yang dapat mempengaruhi manajemen laba seperti 
likuiditas, kepemilikan manajemen, kompensasi bonus, ukuran komite audit, peran aktif dewan komisaris independen. Pertimbangkan untuk meningkatkan populasi perusahaan yang akan menjadi sampel penelitian tidak hanya perusahaan manufaktur sektor industri dasar dan kimia tetapi juga perusahaan manufaktur sektor lainnya bahkan jenis industri lainnya yang terdaftar di BEI dan menambah jumlah tahun pengamatan agar hasil penelitian lebih dapat di generalisasi. Pertimbangkan penggunaan indeks perataan laba lain yang lebih up to date daripada indeks Eckel, misalnya indeks Michelson.

\section{DAFTAR PUSTAKA}

Abiprayu. 2011. Pengaruh Profitabilitas, Ukuran Perusahaan, Financial Leverage, Kualitas Audit, dan Devidend Payout Ratio Terhadap Perataan Laba (Studi Kasus Pada Perusahaan Manufaktur Yang Terdaftar di Bursa Efek Indonesia Tahun 2006-2009). Skripsi Universitas Diponegoro: Semarang.

Agnes Sawir. 2003. "Analisis kinerja keuangan dan perencanaan keuangan perusahaan". Jakarta: PT Gramedia pustaka utama.

Aji Dhamar Yudho dan Mita Aria Farah, Pengaruh Profitabilitas, Risiko Keuangan, Nilai Perusahaan, dan Struktur Kepemilikan Terhadap Praktek Perataan Laba: Studi Empiris pada Perusahaan Manufaktur yang Terdaftar di BEI, SNA XIII, Purwokerto : 2010.

Ashari, N., Koh H.C., Tan S.L., dan Wong W.H., 1994. "Factors Affecting Income Smoothing Among Listed Companies in Singapore". Business \& Accounting Research, Vol 24, No. 96 Autumn, pp. $291-304$.

Assih, Prihat dan M. Gudono. 2000. Hubungan Tindakan Perataan Laba dengan Reaksi Pasar Atas Pengumuman Informasi Laba Perusahaan yang terdaftar di Bursa Efek Jakarta. Jurnal Riset Akuntansi. Vol. 3. No. 1. Januari : 35-53.

Augusty, Ferdinand, 2006. Metode Penelitian Manajemen: Pedoman Penelitian Untuk Penulisan Skripsi, Tesis dan Disertasi Ilmu Manajemen. Badan Penerbit Universitas Diponegoro. Semarang.

Bartov, E., F. Gul, dan J. Tsui, 1993, "Discretionary-Accruals Models and Audit Qualification", Working Paper.

Budhijono (2006). "Evaluasi Perataan Laba Pada Industri Manufaktur dan Lembaga Keuangan yang Terdaftar di BEJ", Akuntabilitas, September 2006,htm.70-79.Vol.6 No.1.

Budiasih Igan, Faktor - Faktor Yang Mempengaruhi Praktik Perataan Laba, Fakultas Ekonomi Universitas Udayana. 2009.

Cornett M. M, J. Marcuss, Saunders dan Tehranian H. (2006). Earnings Management, Corporate Governance, and True Financial Performance.www.papers.ssrn.com.

Dascher, Paul E, dan Robert E. Malcolm, "A Note on income Smoothing in The Chemical Industry", Journal of Accounting Research, Autumn 1970.

Dewi dan Carina, 2008. Faktor-Faktor yang Mempengaruhi Laba Akuntansi dan Laba Tunai terhadap Dividen Kas pada Perusahaan Manufaktur Lembaga Keuangan Lainnya yang Terdaftar di Bursa Efek Jakarta. Jurnal Akuntansi Tahun XII, No. 2,Mei, hal: 117-131

Dwi Prastowo, Rifka Julianty (2010). Analisa Laporan Keuangan;Konsep dan Aplikasi Edisi Revisi. Yogyakarta:YKPN

Eckel, Norm. 1981. The Income Smoothing Hypothesis Revisted Abacus, june : 28-40. Financial Accounting Standards Boards. 1978. Statement of financial Accounting concept No. 1: objectives of Financial Reporting by business enterprises.

Ghozali Iman dan Chariri Anis, Teori Akuntansi Edisi 3, Badan Penerbit Universitas Diponegoro : 2007 
Ghozali, Imam. 2007. Aplikasi Analisis Multivariate dengan Program SPSS. Semarang: Badan Penerbit Universitas Diponegoro.

Gujarati, Damondar. 2006. Dasar-dasar Ekonomitrika.. Julius A. Mulyadi dan Yelvi Andri (penterjemah). Penerbit Erlangga, Jakarta.

H. Sutrisno, Manajemen Keuangan (Teori dan Aplikasi), PT. Ekonisia Kampus Fakultas Ekonomi UII Yogyakarta, Yogyakarta : 2009.

Hapsari, T. Niken. 2010. Seluk Beluk Promosi dan Berbisnis. Yogyakarta: A Plus Books.

Harahap Sofyan Syafri, Teori Akuntansi. Edisi Revisi, PT Raja Grafindo Persada, Jakarta : 2007

Horne, V \& Wachowicz, J. (2007). Prinsip-Prinsip Manajemen Keuangan, buku dua. Jakarta : Salemba Empat

Jensen, Michael C. dan William H. Meckling. 1976. Theory of the Firm : Managerial Behavior, Agency Costs and Ownership Structure.

Juniarti dan Corolina. 2005. Analisa Faktor-faktor yang berpengaruh pada Perataan.

Kumaladewi. 2008. Pengaruh Perubahan Return on Assets, Perubahan Perating Profit Margin, dan Ukuran Perusahaan Terhadap Kemungkinan Praktek Perataan Laba Pada Perusahaan Manufaktur Yang Terdaftar di Bursa Efek Indonesia. Yogyakarta : FE Universitas Atma Jaya Yogyakarta.

Panjaitan, Yunia, Dewinta, Oky, dan Desinta K. Sri, 2004. Analisis Harga Saham, Ukuran Perusahaan dan Risiko Terhadap Return yang Diharapkan Investor Pada PerusahaanPerusahaan Aktif. Jurnal Akuntansi, Auditing, dan Keuangan Universitas Atmajaya, Vol 1. No. 1.

Prabayanti, Ni Luh Putu Arik dan Yasa, Gerianta Wirawan (2010)." Perataan Laba (Income Smoothing) Dan Analisis Faktor-Faktor Yang Mempengaruhinya (Studi Pada Perusahaan Manufaktur Yang Terdaftar Di Bursa Efek Indonesia). Fakultas Ekonomi, Universitas Udayana.

Prasetio. 2002. "Pengaruh Tingkat Profitabilitas Perusahaan dan Leverage Operasi terhadap Tindakan Perataan Laba pada Perusahaan Manufaktur Yang Terdaftar Di BEJ Periode 2003 - 2006”. Skripsi. Fakultas Ekonomi Universitas Udayana.

Riduwan dan Sunarto. 2012. Pengantar Statistika. Penerbit Alfabeta, Bandung.

Rivard, Richard. J., Eugene B dan Gay B.H. Morris. 2003. Income Smoothing Behaviour of V.S Banks Under Revised International.

Septoaji, Arwinto. 2002. "Analisis Faktor-Faktor yang Mempengaruhi Perataan Laba Pada Perusahaan Go Public di Bursa Efek Jakarta" Semarang: Fakultas Ekonomi Universitas Diponegoro.

Suad Husnan. 2004. Dasar-dasar Manajemen Keuangan. UPP AMP YKPN, Yogyakarta.

Sugiyono. 2012. Metode Penelitian Kuantitatif, Kualitatif dan $R \& D$. Penerbit Alfabeta, Bandung.

Suwito dan Arleen. 2005. "Analisis Pengaruh Karakteristik Perusahaan Terhadap Tindakan Perataan Laba yang Dilakukan oleh Perusahaan Yang Terdaftar Di Bursa Efek Jakarta". Simposium Nasional Akuntansi VIII .Solo.15-16 September.

Watts, Ross L., and J L Zimmerman. (1986), Positive Accounting Theory, New Jersey: Prentice-Hall, Inc.

Yusuf, Muhammad,. Soraya. 2004. Faktor-Faktor Yang Mempengaruhi Praktik Perataan Laba Pada Perusahaan Asing Dan Non Asing Di Indonesia. JAAI Volume 7, Jakarta. 